\title{
The Diversity Of Butterfly (Rhopalocera) Based On Environmental Conditions In Muria Kudus Tourism Area Central Java
}

\author{
Umu Zulfatu Rizki $^{1^{*}}$ Lianah $^{1}$, Saifullah Hidayat ${ }^{2}$ \\ ${ }^{1}$ Biology Study Program, Faculty of Science and Tecnology, UIN Walisongo Semarang \\ ${ }^{2}$ Biology Education Study Program, Faculty of Science and Technology, UIN Walisongo Semarang \\ *email : ummuzlf@gmail.co.id
}

Article Info

Key word:

Butterflies

Environmental conditions

Tourist areas

Article history:

Received: 06/12/2020

Revised: 06/01/2021

Accepted: 01/07/2021

\begin{abstract}
Mount Muria has abundant natural resources, both flora and fauna, one of which is butterflies. Butterflies as natural pollinators have an important role in the ecosystem. The deterioration of air quality has a negative impact on butterflies because they are quite sensitive to poor air quality and poor lighting. This study aims to analyze the relationship between environmental conditions and butterflies in the Muria Kudus area, carried out in March and June 2020. Butterfly observations were carried out using the quadratic sample transect method with 3 observation stations and measured environmental factors, among others: temperature, humidity, light intensity, altitude and $\mathrm{Pb}$ concentration analysis with AAS. The results of the study found 40 species of butterflies consisting of 6 families, with a moderate diversity index, almost merit index and low dominance. Muria area still has good environmental conditions for butterfly breeding. Relative abundance is negatively correlated with light intensity $\left(r_{\text {count }}=-0,855, r_{\text {table }}=0,811\right)$. Averageness is negatively correlated with heigh $\left(r_{\text {count }}=-\right.$ $\left.0,836, r_{\text {table }}=-0,881\right)$. The butterfly species Ypthima nigricans, Orsotriaena medus, and Melanitis leda is a specialist butterfly species and the butterfly species Papilio memnon, Leptosia nina, Chersonesia rahria, Mycalesis horsifieldii, and Yphtima horsifieldii is a generalist species butterfly.
\end{abstract}

Copyright $($ C) Author(s). All Right Reserved

\section{Introduction}

Mount Muria is one of the areas in Central Java which is part of the eastern part of Kudus Regency. Mount Muria has quite a lot, and varied biodiversity, both in the form of flora and fauna. Perum Perhutani Forest Management Unit (KPH) Pati noted Mount Muria's biodiversity, among others, there are 80 types of trees, palms tree, and grasses.
The types of fauna found include five types of (Javanese cobra), green pythons, wild boar (Sus scofa), deer (Muntiacus muntjak), langurs (Trachypithecus auratus), longtailed monkeys (Macaca fascicularis), hedgehogs (Hystrix javanica) etc (Widjanarko, 2016). Muria area has many tourist attractions, including the tomb of Sunan Muria, Montel Waterfall and Three 
Taste Water Rejenu. Visitors to Muria Area are increasing every year (BAPPEDA Kab. Kudus, 2020). This has a positive impact on the economy of the surrounding community but also has a negative impact on the environment by decreasing air quality (BAPPEDA Kab. Kudus, 2021).

Motorized vehicles have a large enough effect on the air because exhaust fumes from motorized vehicles contain lead $(\mathrm{Pb})$ metal compounds. Lead $(\mathrm{Pb})$ emissions to the air are the result of incomplete combustion of motor engines (Sari, 2016). Air quality has a negative impact on living things, both flora and fauna. One of them is against butterflies, because butterflies are very sensitive to poor air quality and insufficient sunlight. Butterflies are sensitive to certain environmental conditions and like an environment that is not polluted (Sulistyani et al, 2014). Butterflies have an important role in the balance of ecosystems in nature, as pollinators in the process of plant (Braby, 2016). This causes butterflies to take part in maintaining the balance of the ecosystem and enriching natural biodiversity.

In general, butterflies (Rhopalocera) are active during the day looking for nectar. Butterflies need light heat because butterflies are cold-blooded orpoikilothermal (Baskoro, et al, 2018). According to (Ghazoul, 2002) butterflies are a good type of insect to monitor changes in biodiversity or the environment. Azahra et al (2016) research, the abundance and diversity of butterflies decrease with increasing environmental disturbance. Research on the relationship between butterfly community and environmental conditions has been done a lot, including research by Azahra et al (2016) which examines the comparison of butterfly communities on various types of environmental characteristics and disturbances of urban forest in East Jakarta Municipality, Ghazoul (2002), research on the impact of logging on tropical forest butterflies in Thailand, (Sulistyani et al, 2014), regarding the diversity of butterflies in the Ulolanang Kecubung Nature reserve in Batang Regency, as well as research on environmental characteristics of the environment in Banyumas (Rezzafiqrullah et $a l, 2018)$, but research in the Muria Kudus area is not yet available specific data on the relationship of butterfly communities with environmental conditions in the Muria Kudus area. Based on this, it is necessary to conduct research aimed at analyzing the relationship between butterfly abundance and diversity with environmental conditions in the Muria Kudus area.

\section{Materials and Methods}

This research was conducted in March, and June 2020 in Colo Village, Dawe District, Kudus Regency (Figure 1). This research is a field research with a descriptive approach.

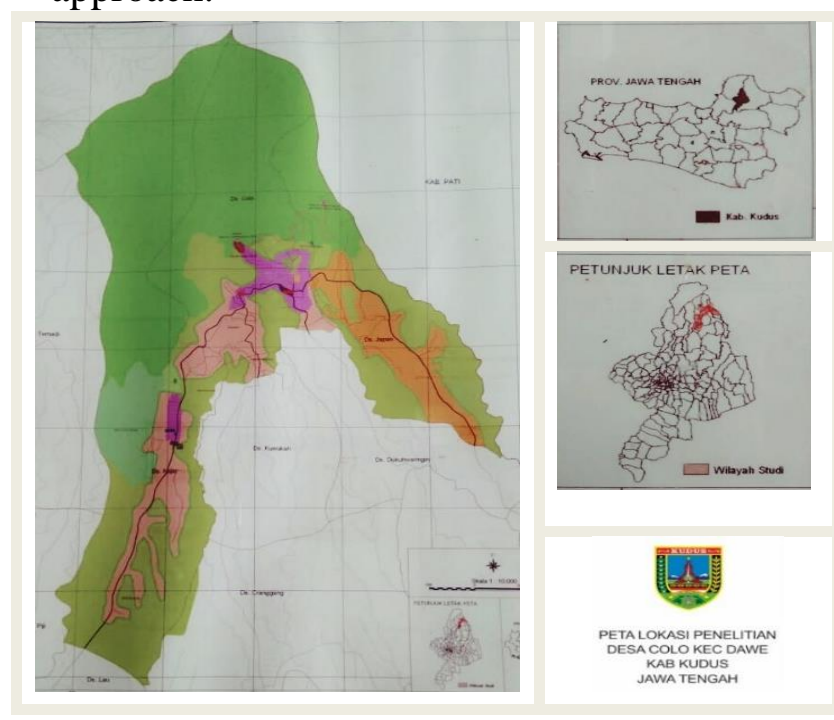

Figure 1 Map of Masterlan of Mount Muria region (BAPPEDA Kudus Regency,2021)

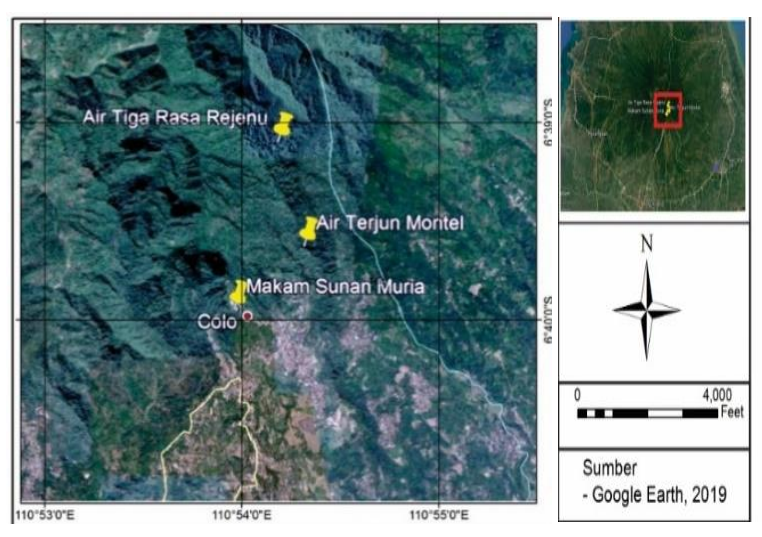

Figure 2 Location of Observation (Google Earth, 2019) 
Butterfly sampling was carried out using the transect method. There are 3 observation stations, ie the Kembang river, the Montel Waterfall tour and the Three Taste Water Rejenu (Figure 2). Each station is divided into 3 plots. Butterfly observations were carried out at 08.00-15.00 WIB. The tools used in this research are insect nets, roll meter, camera, loop,box, luxmeter, hygrometer, thermometer, anenometer, Global Positioning System (GPS) and butterfly identification book, ie Lepidoptera Semarang Raya (Baskoro et al, 2018) and Pratical Guide to The Butterflies of bogor Botanic Garden (Peggie, 2006). The materials needed are cotton, 70\% alcohol, chlorophome and formalin.

Data collection for butterfly species was carried out by observing the research location by recording all data on butterfly species, and butterfly abundance. Measurements of environmental factors include:air temperature, air humidity, light intensity, altitude and concentration of lead $(\mathrm{Pb})$. Measurement of lead concentration $(\mathrm{Pb})$ was carried out using gravimetric methods and ashes extraction using AAS (Atomic Absorption Spectrophotometer) with leaf samples.

Data analysis including diversity index (H '), Evennes index (E), species dominance index (D), relative abundance (KR) and the relationship between diversity and abundance of butterflies with environmental characteristics were analyzed using the Pearson correlation test.

\section{Results and Discussion}

\section{A. Butterfly Species Composition}

Based on the results of the research from the three observation locations, there were as many as 40 species of butterflies consisting of 6 families (table 1), ie Papilionidae (2 species), Pieridae (4 species), Nymphalidae family (25 species), Rionidae (1 species). Lycaenidae (4 species) and Hesperidae (4 species) (Figure 3 ). The most common butterflies found in the Nymphalidae family are 25 species, this is because the Nymphalidae family has the most species in the Lepidoptera order, besides this family has a wide distribution (Dendang, 2008). There are still various species of butterflies in the observation location, indicating that the three locations are included in the butterfly habitat. The most butterfly species were found in station III with 33 species of butterflies, followed by station I with 32 species and station II with the least 28 species of butterflies.

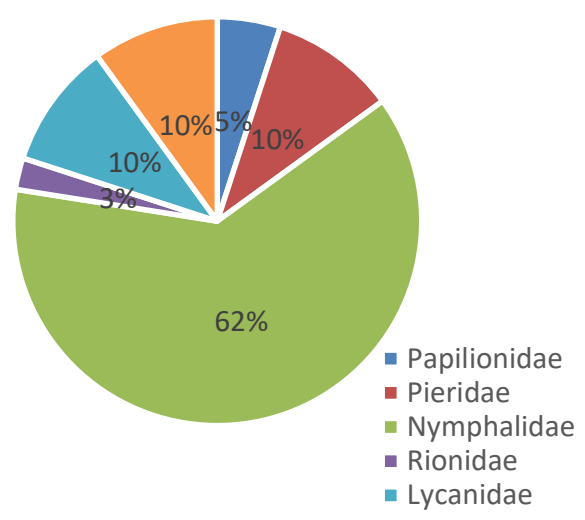

Figure 3. The Family of Butterflies in the Muria Kudus

\section{B. Data Analysis}

Butterfly diversity index from each area was analyzed using Shannon Wiener diversity index, on the analysis results at all stations has diversity by category moderate, that is, with a value of 2.932 at station I, 2.829 at station II and 2.685 at station III. According to (Magurran, 1988), the diversity index value is generally 1.5 to 3.5 and very rarely reaches 4 . Even though it has the same index range, namely the level of diversity that is moderate at station II with stations I and III has a relatively large difference. Stations II has the smallest diversity index. This is due to the smaller vegetation structure in station II compared to the other two stations.

The highest relative abundance index at station I was Papilio memnon with a value of 0.139 , station II had the highest value for Mycalesis horsifieldii with a value of 0.183 and station III was Leptosia nina with a value of 0.214 . Abundance in these three species. The evenness index of butterflies in the three research locations was analyzed 
using the Simpson evenness index, the results of the analysis showed that the evenness of the three observation locations was almost evenly distributed. At station I the evenness index value is 0.846 , at station II it has an evenness index of 0.849 and at station II it has an evenness index of 0.770 . Similar to the diversity index on the evenness index, the lowest number is also found at station II.

The dominance index value at the three research locations has a low dominance index value. The dominance value at station I was 0.064 , at station II was 0.073; and station III at 0.097. The numbers that appear from the three stations are close to the minimum value of dominance, according to (Purwowidodo, 2015) the minimum number on the dominance index shows that the individual abundance of butterfly species does not appear to have a prominent dominance phenomenon.

Table 1. The results of the analysis of the diversity index, evenness index and species dominance index

\begin{tabular}{cccc}
\hline \multirow{2}{*}{ Station } & \multicolumn{3}{c}{ Index } \\
\cline { 2 - 4 } & H' & E & D \\
\hline Station I & 2.932124 & 0.846032 & 0.064356 \\
Station II & 2.829612 & 0.849171 & 0.073444 \\
Station III & 2.685737 & 0.770979 & 0.097360 \\
\hline
\end{tabular}

\section{Environmental Conditions in Muria Kudus Area}

Environment is a factor that influences the presence of organisms in a habitat. Table 2 shows the good environmental conditions in the Muria Kudus area. This can be seen from the concentration of lead metal $(\mathrm{Pb})$ in the three locations which is still below the national ambient air quality standard, which is less than $2 \mathrm{ug} / \mathrm{m} 3$ based on Government Regulation (No.41 of 1999). However, even though the concentration of lead metal $(\mathrm{Pb})$ is still below the standard quality, is still dangerous for living things around it, because if the organism is exposed for a long time, these pollutants will accumulate in its body and can have a negative impact on its survival and reproduction (Azahra et $a l$, 2016). Lead metal $(\mathrm{Pb})$ is a heavy metal that is carcinogenic because it can cause cell mutations and in the long term its toxicity does not change (Sari, 2016).

Based on the results of measurements of environmental factors, temperature, humidity, light intensity and $\mathrm{Pb}$ concentration (table 3) in the three observation locations are still categorized as good for butterflies, so that butterflies can breed well in that area. Therefore, the types of butterflies found in these three areas are quite diverse. Butterflies are poikiloterm, that is, animals whose temperature is influenced by the environment so that butterfly activity is determined by environmental temperature (Kurnianto, 2016). The temperature at the observation location shows a range between 28.65-31.5 ${ }^{\circ} \mathrm{C}$, this temperature is still considered ideal for butterflies. In addition, humidity is also a factor that affects the presence of butterflies (Braby, 2016). Butterflies cannot live in very high humidity. In the observation, the humidity range in the Muria Kudus area is $62-68 \%$, high humidity reaches $90 \%$ and above. According to Pollard \& Yates (1993), sunlight can affect the ability to fly butterflies, butterflies visit flowers in the morning at 08.00-11.00 when the sun is shining enough and dry their wings while sunbathing (Lestari et al, 2015).

Table 2 Environmental Parameters at Three Stations in Muria Kudus Tourism Area

\begin{tabular}{lccc}
\hline \multirow{2}{*}{ Environment } & \multicolumn{3}{c}{ Station } \\
\cline { 2 - 4 } & I & II & III \\
\hline Temperature $\left({ }^{0} \mathrm{C}\right)$ & 30.2 & 31.5 & 28.65 \\
Humidity $(\%)$ & 62.6 & 68.9 & 68.15 \\
Light intensity $(\mathrm{cd})$ & 615.4 & 540.4 & 554.9 \\
Altitude $(\mathrm{mdpl})$ & 635 & 733 & 856 \\
Lead Concentation $(\mathrm{Pb})$ & 1.604 & 0.882 & 0.687 \\
\hline
\end{tabular}

\section{Relationship between Butterfly Community and Environmental Characteristics}

Environmental characteristics in a habitat can affect the butterfly community, person correlation analysis is used to determine the relationship between butterfly 
community parameters (dependent variable) and environmental parameters (independent variable). Pearson correlation analysis shows increasing relative abundance of a habitat is negatively correlated with intensity light $\left(\mathrm{r}_{\text {count }}=-0,855, \quad \mathrm{r}_{\text {table }}=0,811\right)$ with significant value. This matter indicates that the higher the intensity light results in relative abundance butterflies decline. Light intensity is one factor affect the increase in air temperature, vision, larval development, flight activity and butterfly metabolism butterflies (Azahra et al, 2016). Other than that Pearson correlation analysis shows negative correlation between heights habitat with an evenness of butterflies $\left(r_{\text {count }}=-0,836\right.$, $r_{\text {table }}=-0,881$ ). The evenness of the butterfly is decreasing in the higher habitat. This matter according to the evenness index analysis at all three research locations that value the smallest is at station III which is has the highest altitude (856 masl). In Abdu's research (2016) on an altitude of 800 masl has decreased at butterflies due to climate adaptation and availability of food.

Table 3 Results of Pearson Correlation Analysis between environmental factors and the butterfly community

\begin{tabular}{ccccc}
\hline Environment variable & KR & H' & E & D \\
\hline Lead $(\mathrm{Pb})\left(\mu \mathrm{g} / \mathrm{m}^{3}\right)$ & 0,536 & $-0,020$ & 0,701 & 0,079 \\
Temperature $\left({ }^{\circ} \mathrm{C}\right)$ & $-0,246$ & 0,263 & 0,076 & 0,270 \\
Humidity $(\%)$ & $-0,202$ & $-0,855^{* *}$ & 0,076 & $-0,270$ \\
Light Intensity $(\mathrm{cd})$ & $-0,673$ & 0,278 & $-0,836^{* *}$ & 0,400 \\
\hline
\end{tabular}

Note $\quad:$ H': Diversity, KR: Relativ abundance, E: Evenness, D: Dominance, **: Significant with a confidence level of $95 \%$.

Based on the level of sensitivity, tolerance and adaptability to different environmental conditions, the species of organisms are divided into specialist species and generalist species. Specialist species are species whose existence is affected by certain environmental factors, butterfly types that are found only in one observation location and generalist species are species whose existence is not affected by certain environmental factors, butterflies that are found in all observation locations (Rezzafiqrullah et al, 2018). Butterflies that were only found in one observation location Ypthima nigricans, Orsotriaena medus, and Melanitis leda are butterflies that are categorized as specialist species. Butterflies found in all observation locations ie Papilio memnon, Leptosia nina, Chersonesia rahria, Mycalesis horsifieldii, and Yphtima horsifieldii are butterflies that are categorized as generalist species.

\section{Conclusion}

The results of the study found 40 species of butterflies with the diversity index analysis of the three stations classified as moderate, the evenness index analysis classified as almost even and the dominant species analysis was low. Muria Kudus area still has good environmental conditions with $\mathrm{Pb}$ concentration values still below quality standards and good environmental factors for butterflies.

\section{References}

Azahra, S. D., Masy'ud, B., \& Farikhah, N. 2016. Comparison of Butterfly Communities in Different Types of Characteristics and Disturbances of the Urban Forest Environment. Conservation Media, 21 (2), 108-115 https://media.neliti.com/media/publica tions/231382.pdf

BAPPEDA Kab. Kudus, 2021. Perbup Satu data Kabupaten Kudus. https://bappeda.kuduskab.go.id/detaildokumen.php?id=202

Baskoro, Karyadi. 2018. Lepidoptera Semarang raya. Atlas. https://www.researchgate.net/publicati on/324006052.Atlas.Biodiversitas

Braby, M, F. 2016. The Complete Field Guide to Butterflies of Australia 
Second Edition. (Australia v: CSIRO Publication, 2004)

Dendang, B. 2008. The diversity of butterflies at Selabintana Resort, Gunung Gede Pangrango National Park, West Java. Journal of Forest Research and Nature Conservation, 6 (1), 25-36. doi.10.20886/jphka.2009.6.1.25-36

Ghazoul, J. 2002. Impact of Logging on The

Richness and Diversity of Forest Butterflies in a Tropical Dry Forest in Thailand. Biodiversity and Conservation, (11): 521-541. doi.10.1023/A:1014812701423

Government Regulation No 41 of 1999. Accessed on 12 July 2020

Kurnianto, S.H., I.Y Wafa., F Alifianto \& N Kurniawan. 2016. Potential of Butterfly in Tourism Diversification Product : Case Study at Coban Rais Waterfall, Batu, East Java. Journal of Indonesia Tourism and Development Studies. $\quad$ Vol 4 No3. https://jitode.ub.ac.id/article/187/pdf_1

Lestari, D. F., R. D. A., Ridwan, M., \& Purwaningsih, A. D. 2015. Diversity of butterflies (Insect Lepidoptera) in Alas Bromo Karanganyar. Pros Sem Nas Masy Biodiv Indon, 1(6), 12841288. dio.10.13057/psnmbi/m010604

Magurran, A. 1988. Ecological Diversity and is Measurement. Princenton New Jersey: Princenton Univercity Press.

Peggie, Djunijanti and Amir, Muhammad. 2006. Pratical Guide to The Butterflies of Bogor Botanic Garden. Bogor : LIPI.

Pollard, E and Yates, T.J. 1993. Monitoring Butterflie for Ecology and Conservation. Champman \& Hall. London. https://link.springer.com/book/978041 2402203

Purwowidodo. 2015. Study of Biodiversity of Butterflies (Sub Ordo Rhopalocera) and Their Ecological Role in the Protected Forest of the Foot of Mount Prau Forest, Kendal Regency, Central Java. Walisongo State Islamic University Semarang.

Rezzafiqrullah, M., Taradipha, R., Rushayati, S. B., \& Haneda, N. F. 2018. Environmental characteristics of insect communities. Journal of Natural Resources and Environmental Management, 9 (2), 394-404. doi.10.29244/jps1.9.2.394-404

Sari, Fanni Riyantika., Purnomo, Tarzan., and Rachmadiarti, Fida. 2016. The ability of Betel Gading (Epipremnum aureum) as an absorbent for heavy metal lead $(\mathrm{Pb})$ in the air. LenteraBio. Vol 5 no.3

Sulistyani, Teguh Heny., Rahayuningsih, Margerata, \& Partaya. 2014. Diversity of Lepidoptera Butterflies: Rhopalocera in the Ulolanang Kecubung Nature Reserve, Batang Regency, Bioecology Journal, vol.2, no.1.

https://journal.unnes.ac.id/sju/index.ph p/UnnesJLifeSci/article/view/2977

Widjanarko, Mochamad. 2016. Social Capital for the Community of Rahtawu Village, a Case Study of Muria Forest Conservation in Kudus Regency. Journal of Society and Culture. Vol 18 no.1. https://jmb.lipi.go.id/jmb/article/view/ 344/294 